\title{
FISH PREDATION IN THE PROXIMITY OF PURSE SEINE FISHING LIGHTS: THE CASE OF ATHERINA BOYERI (ACTINOPTERYGII: ATHERINIFORMES: ATHERINIDAE) IN A GREEK LAKE
}

\author{
George KEHAYIAS*, Anastasia TZAVALI, Marilia GINI, Ekaterini MICHOPOULOU, \\ and Lambros TSOUNIS
}

Department of Environmental and Natural Resources Management, University of Patras, Agrinio, Greece

\begin{abstract}
Kehayias G., Tzavali A., Gini M., Michopoulou E., Tsounis L. 2018. Fish predation in the proximity of purse seine fishing lights: The case of Atherina boyeri (Actinopterygii: Atheriniformes: Atherinidae) in a Greek Lake. Acta Ichthyol. Piscat. 48 (1): 51-60.
\end{abstract}

\begin{abstract}
Background. Purse seining with the use of light is among the most common fishing practices around the world, but there is lack of studies on the effect of light on the feeding of the target species in this kind of fishery and the possible consequences for other prey species. The presently reported investigation intended to provide indications on this issue by studying the diet of Atherina boyeri Risso, 1810, which is the target species of professional purse seine fishery, conducted using light in Lake Trichonis (Greece), and by comparing the acquired results with those of previous studies where the samples were taken without using light.

Materials and methods. A seven-month (June through December 2014) purse seining fishing was conducted at night around two lamp rafts: 1) a traditional lamp raft producing white LED light and 2) an autonomous photovoltaic-battery-LED lamp raft producing green LED light. Stomach content analysis was conducted on 100 randomly selected specimens from each sample and the relative prey abundance and frequency of occurrence for each prey category was estimated. Calculations of predation pressure of $A$. boyeri upon the fish larvae of a goby, Economidichthys trichonis Economidis et Miller, 1990, were performed.

Results. The study revealed the intense effect of light on the attraction and capture of prey species rarely found in previous studies, such as the larvae of the native and endangered fish E. trichonis, amphipods, and copepod nauplii. No significant differences were observed between the two light colours. A preference shift to larger prey with the increase of ontogenetic stage of $A$. boyeri was observed. Several thousands of pre-recruited E. trichonis larvae may be preyed upon each night around a single lamp especially during summer.

Conclusion. Fishing with light may alter the dietary preference of the target fish species and even of the entire fish community. This may have serious consequences on the younger ontogenetic stages of other fish populations, especially when it coincides with their reproductive period. Considering the lack of similar field studies, the present results may stimulate analogous investigations on the effects of fishing lights in other marine and freshwater ecosystems worldwide.
\end{abstract}

Keywords: feeding, purse seine, Atherina boyeri, LED light

\section{INTRODUCTION}

The purse seine is a common fishery method targeting epipelagic fishes in numerous marine and freshwater areas all over the world and in many cases it is carried out at night using light lures (Ben-Yami 1976, Acros and Oro 2002). The method employs the use of lamp rafts equipped with various sources of light, such as kerosene or liquefied petroleum gas lamps, battery-powered incandescent bulbs, and fluorescent or LED lamps (McHenry et al. 2014, Mills et al. 2014). Purse seining with light is among the most important fishing practices in the Mediterranean Sea being able to harvest large quantities of shoaling fish such as sardinella, sardine, anchovy, mugilids, horse mackerel, sand smelt, etc. (Papaconstantinou and Farrugio 2000, El-Haweet 2001, Tsitsika and Maravelias 2008). The typical purse seine practice involves anchoring lamp rafts with their lights turned on for some time in order to attract a fish school. When a dense aggregation of fish has formed, the main fishing boat encircles the school by releasing the seine net with the assistance of a small rowing boat. The base of the seine then closes to form a bag-shaped net that encloses the fish. Finally, the full net is brought alongside the main vessel (Tsagarakis et al. 2012).

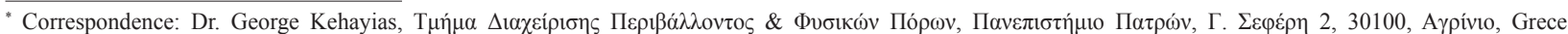
phone: +30 26410-74136, fax: + 30 26410-74176, e-mail: (GK) gkechagi@upatras.gr, (AT) tzavali23@hotmail.com, (MG) marilia.sagiouri@gmail.com, (EM) katerinam16@hotmail.com,(LT) ltsounis@upatras.gr.
} 
It has been known for centuries that fish are attracted to light. Light in water triggers the positive phototactic reaction of the zooplankton located close to the light source. Shortly afterwards, fish larvae and zooplanktivorous fish follow to take advantage of the accumulation of prey, while their presence draws in larger fish species and even top predators in a trophic chain reaction (Maéda 1951, Ben-Yami 1976). Given the economic and ecological significance of using light in fishing, many studies deal with the reaction of fish species to various light intensities and wavelengths (Maéda 1951, Ben-Yami 1976, Marchesan et al. 2005, Okamoto et al. 2008, Matsushita et al. 2012) and the adaptation of fishing gear (Sokimi and Beverly 2010, Kehayias et al. 2016). However, although it is known that fish approach light sources in order to feed, there is a lack of field studies on how the presence of light can influence their feeding preferences.

Purse seine fishing with the use of light has been carried out in Lake Trichonis (Greece), where a landlocked population of Atherina boyeri Risso, 1810 is the target fish species. Atherina boyeri was naturally introduced into this ecosystem from the sea via river channels in past centuries and has great commercial importance as it is the main source of fishing revenue (Leonardos 2001). The Greek legislation allows only three fishing boats to conduct the commercial fishing of A. boyeri in Lake Trichonis using the purse seine method with light rafts for a year-round period (except in MarchApril and between 15 June and 20 July). According to the local fishing practice, from June through December the local fishermen exercise the purse seining mainly at night using light for the fish attraction, while for the rest of the year they fish only in daylight hours tracking $A$. boyeri schools with sonar devices.

Two previous studies on the diet and feeding strategy of $A$. boyeri in Lake Trichonis (Chrisafi et al. 2007, Doulka et al. 2013) revealed that it is a strictly zooplanktivorous species that acts as a visual predator and feeds not only according to the abundance of prey, but also selects prey categories in respect to size, species and even gender (Doulka et al. 2013). It must be pointed out, however, that these studies have been conducted in specimens from samples taken without the use of light, and thus, there are no indications of how the presence of light can differentiate the feeding habits of this species.

Field studies in Lake Trichonis have shown that zooplankton as well as fish larvae are attracted to light and can be caught in light traps (Kehayias and Doulka 2007). In addition, Doulka et al. (2013) showed that $A$. boyeri is capable of preying upon the larvae of the endangered fish, Economidichthys trichonis Economidis et Miller, 1990, for which field experiments have revealed intense positive phototactic behaviour (Kehayias, unpublished data). Therefore, it is highly probable that the larvae of this endangered species approach the purse seine lamp rafts deployed at night and suffer heavy predation by $A$. boyeri when the latter aggregates around the light (Kehayias et al. 2015). In this case, purse seine fishing with the use of light may raise a conservation issue for E. trichonis.
Considering the above, the presently reported study intended to investigate the possible consequences of the use of light for fishing during the period of its implementation (June through December) in Lake Trichonis. Among the goals of this investigation was answering the following questions: 1) What is the diet of a fish species (A. boyeri) preying close to an artificial light source such as the typical purse seine lamp raft? 2) How does this diet compare to the usual feeding preferences of this species based on previous studies? 3) Are there any dietary variations with respect to: a) the different ontogenetic stages of $A$. boyeri, b) the month/season, and c) the colour of the artificial light used? 4) What are the possible ecological consequences of the purse seine fishing practice for specific prey species in Lake Trichonis? Finally, considering the absence of similar field studies, the presently reported study anticipates an encouragement of analogous investigations in other marine and freshwater ecosystems worldwide.

\section{MATERIALS AND METHODS}

Study area. The presently reported study was conducted in Lake Trichonis, the largest natural lake in Greece, which is situated in the western part of the country $\left(38^{\circ} 30^{\prime}-38^{\circ} 36^{\prime} \mathrm{N}, 21^{\circ} 26^{\prime}-21^{\circ} 39^{\prime} \mathrm{E}\right)$. The lake has a surface area of $98.6 \mathrm{~km}^{2}$ and a catchment area of $421 \mathrm{~km}^{2}$. It is a deep $\left(Z_{\max }=57 \mathrm{~m}, Z_{\text {mean }}=29 \mathrm{~m}\right)$, warm monomictic lake, exhibiting a long period of thermal stratification. It is an oligo- to mesotrophic ecosystem and has great ecological importance and is included in the Natura 2000 protection network (Kehayias and Doulka 2014). The lake is very rich in fish species, among which Atherina boyeri dominates (Leonardos 2001).

Field operations. In order to study the diet of $A$. boyer in the presence of light, fish samples were obtained from night purse seine fishing trials conducted in Lake Trichonis from June through December 2014 with the assistance of local fishermen. As previously stated, this particular period of the year was selected in order to coincide with the implementation of the purse seine fishing with the use of light. One fishing trial was conducted each month on a moonless night. Two designs of lamp rafts were used in each trial. The first was the traditional lamp raft (TR) that was built and operated by the local fishermen. The TR is a metal frame construction mounted on plastic barrels. A 12V/60A lead car battery provides the energy to light three $8 \mathrm{~W}$ white LED lamps $(1800 \mathrm{~lm})$ that are attached to a frame suspended approximately $1 \mathrm{~m}$ above the water's surface on one side of the raft. The second lamp raft design was an autonomous photovoltaic-battery-LED lamp raft (APVR) that was introduced by Kehayias et al. (2016). The APVR is equipped with a $30 \mathrm{~W}$ cylindrical LED lamp producing green light $(2400 \mathrm{~lm})$ and is powered by a $12 \mathrm{~V} / 55 \mathrm{~A}$ lead, deep discharge battery that is charged by a $100 \mathrm{~W}$ photovoltaic panel. The LED lamp is positioned underneath an Inox reflector that lies just above the water's surface.

On each sampling occasion, the two light rafts were anchored at a distance of about $200 \mathrm{~m}$ from each other in certain sites on the eastern part of the lake. Just before dark, their lamps were turned on and remained lit for 
several hours (6-8 h depending on the date). Fishing was conducted by a purse seine net (length: $150 \mathrm{~m}$, height: 20 $\mathrm{m}$, mesh size: $6 \mathrm{~mm}$ ), which was deployed around each raft (TR and APVR) before dawn. After retrieving the net, the $A$. boyeri specimens from each catch were placed into wooden crates each of which could accommodate approximately $10 \mathrm{~kg}$. The number of these full crates was used to roughly estimate the total weight of the catch. Immediately after net retrieval a number of randomly selected $A$. boyeri specimens were placed into a $3 \mathrm{~L}$ plastic jar containing $10 \%$ formalin solution to minimize post-capture digestion of prey. For technical reasons, no fish samples were taken in June 2014 from the catch around TR. Video recordings were taken on 21 July 2014 using a remotely operated underwater vehicle (Seabotix LBV200-4) close to one TR lamp raft operating with white LED light.

Laboratory measurements. The samples were transferred to the laboratory, where the total body length (TL) and total body weight (TW) of all A. boyeri specimens were measured. The specimens were separated into four size classes: $L_{1}: \mathrm{TL}<50 \mathrm{~mm}, L_{2}: 50.1<\mathrm{TL}<70 \mathrm{~mm}, L_{3}: 70.1<$ $\mathrm{TL}<85 \mathrm{~mm}$, and $L_{4}: \mathrm{TL}>85.1 \mathrm{~mm}$. Size class boundaries correspond to the total length of the $0^{+}$to $3^{+}$age groups of A. boyeri in Lake Trichonis (Leonardos 2001). Stomach content analysis was conducted in 100 randomly selected specimens from each sample. All prey items within the stomach contents of each specimen containing food were identified under a stereoscope to the lowest taxonomic level possible, given the degree of digestion. Identification of the fish larvae recovered from the stomach contents and being in fairly good condition (not showing pronounced digestion) was based on the morphological descriptions provided by Daoulas et al. (1993).

Data analysis was carried out using the numerical method for each food category (Hyslop 1980). Thus, the relative prey abundance $(\mathrm{PN})$ was calculated as the percentage of the total number of each prey category $i$ $(\Sigma \mathrm{p} i)$ over the total prey items $(\Sigma \mathrm{P})$, as follows:

$$
\mathrm{PN}=\frac{\sum P i}{\sum P} \times 100
$$

The frequency of occurrence $(F)$ was calculated as the percentage of stomachs $\left(n_{i}\right)$ containing prey category $i$ over the total of non-empty stomachs $(N)$ as follows:

$$
F=\frac{n_{i}}{N} \times 100
$$

In order to determine the feeding strategy of $A$. boyeri, the modified Costello graphical method (Amundsen et al. 1996) was used. According to this method, the prey-specific abundance $(P i)$, which is defined as the percentage of a prey item over the total of prey items in only those predators in which the actual prey occurs, is plotted against the frequency of occurrence $(F i)$ on a twodimensional graph.
Comparisons between the length frequency distribution of the $A$. boyeri specimens caught by each lamp raft (TR and APVR) with white and green lights, respectively, were performed using the Kolmogorov-Smirnov test (Zar 1999). Differences of the $F$ and PN values of the prey types among the length classes of $A$. boyeri were investigated with the Chi-square test. Statistical analyses were conducted using the SPSS 20 software. Taking into account the occurrence of larvae of an endangered species like E. trichonis found in the stomach contents of $A$. boyeri, there was an attempt to estimate the total number of larvae preyed upon each night by one fish school aggregated around a single lamp raft. Based on the length measurements of all the specimens in each A. boyeri sample, and assuming that the size distribution in the random sample taken from the catch corresponds to the entire catch, the percentage contribution of the four size classes $\left(L_{1}-L_{4}\right)$ in the catch was found. The total number of $A$. boyeri specimens caught in the purse seine catch $(N)$ was estimated as follows:

$$
N=\frac{W \times n}{w}
$$

where $W$ is the total weight of the catch, $n$ is the total number of $A$. boyeri specimens in the sample, and $w$ is the total weight of the sample. Based on the percentage contribution of $L_{1}-L_{4}$, the numbers of $A$. boyeri specimens in each size class $\left(N_{1}-N_{4}\right)$ were found. The E. trichonis larvae preyed by the $A$. boyeri specimens of each of the four size classes were calculated as follows:

$$
\mathrm{PL}_{1}=N_{1} \times p_{1}
$$

where $\mathrm{PL}_{1}$ is the E. trichonis larvae preyed by the $L_{1}$ size class $A$. boyeri specimens of the catch, and $p_{1}$ is the mean number of $E$. trichonis larvae preyed by one $L_{1}$ size class $A$. boyeri specimen. Accordingly, the calculation of standard error $(\mathrm{SE})$ of the $\mathrm{PL}_{1}$ value $(\mathrm{SE}) \mathrm{PL}_{1}$ was calculated as follows:

$$
\mathrm{SE}_{\mathrm{PL} 1}=N_{1} \times \mathrm{SE}_{p 1}
$$

where $\mathrm{SE}_{p 1}$ is the standard error in the estimation of $p_{1}$.

The total number of E. trichonis larvae preyed upon each night by one fish school aggregated around a single lamp (PL) was the sum of $\mathrm{PL}_{1}$ to $\mathrm{PL}_{4}$.

The presently reported study has been carried out in accordance with the respective Greek regulations.

\section{RESULTS}

A total of 4442 Atherina boyeri specimens were recovered from the samples. There were no differences (Kolmogorov-Smirnov test, $P>0.05$ ) in the length frequency distribution between the specimens caught around the two different light rafts in each month (Fig. 1).

The stomach content analysis of 1300 A. boyeri specimens revealed that their diet consisted of twelve different prey categories (Table 1) representing four major groups: crustaceans (copepods, cladocerans, and 
amphipods), molluscs (Bivalvia), insects, and teleost fish larvae. There were monthly differences in the number of prey categories, with the greatest number (eleven) found in July, while only four in September. There were no statistically significant differences in the $\operatorname{diet}$ of $A$. boyer $i$

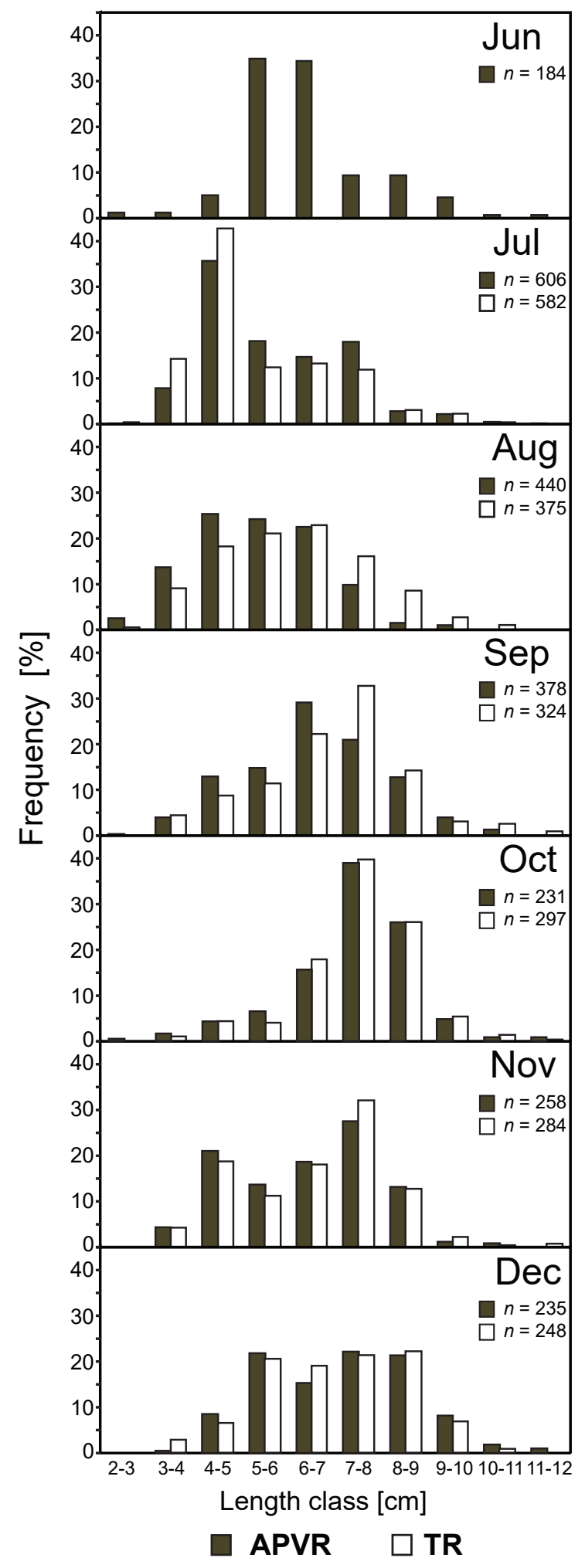

Fig. 1. Length frequency distribution of Atherina boyeri specimens caught around the APVR and TR lamp rafts from June to December 2014 in Lake Trichonis, Greece (for the total number of specimens and for each of the four length classes) caught around the two lamp rafts (Chi-square test, $P>0.05$ ) when testing either for relative prey abundance $(\mathrm{PN})$ or for frequency of occurrence $(F)$. The bivalve larvae of Dreissena blanci were the dominant prey as shown by their PN and $F$ values compared to other prey categories in the samples caught around both lamp rafts (Table 1). The larvae of Economidichthys trichonis followed, with their frequency of occurrence $(F)$ fluctuated between $9.40 \%$ and $55.95 \%$. Almost all the E. trichonis larvae found were in such a digestive condition as to permit their identification. These two main prey types were followed by several other taxa such as the cladoceran Bosmina longirostris, the calanoid copepod Eudiaptomus drieschi, amphipods, copepod nauplii, cyclopoid copepods, and the cladoceran Diaphanosoma orghidani. Apart from the aforementioned taxa, the cladocerans Daphnia cucullata and Ceriodaphnia pulchella, as well as a few terrestrial insects and larvae of $A$. boyeri, were also found occasionally in the stomach contents of the specimens caught around the two lamp rafts (Table 1).

The $A$. boyeri specimens of the four length classes $L_{1}-$ $L_{4}$ showed definite differences in their diets considering the pooled data from both lamp rafts (Fig. 2). Specifically, stomach content analysis of the younger specimens $\left(L_{1}\right.$ and $L_{4}$ ) revealed the generally greater frequency of occurrence $(F)$ of smaller prey categories such as nauplii, D. blanci larvae, and $B$. longirostris. On the other hand, the larger specimens $\left(L_{3}\right.$ and $\left.L_{4}\right)$ showed greater $F$ values for larger prey such as E. trichonis larvae and amphipods (Fig. 2). However, such differences in $F$ were statistically verified only in the case of the larvae of E. trichonis (Chi-square test, $P=0.035)$, while this was also the case considering the PN (Chi-square test, $P=0.046$ ), with increased values recorded in the larger $A$. boyeri specimens.

Atherina boyeri demonstrated an apparent feeding strategy with great specialization towards one single prey type, the larvae of the bivalve $D$. blanci, being the dominant prey for almost all specimens of this fish (Fig. 3 ). The placement of the other types of prey in the lower left area of the modified Costello diagram indicates that small proportions of these prey types were included occasionally in the diet of some individuals, reflecting a predator population with a narrow niche width (Fig. 3). The fish larvae of E. trichonis seem to stand as another significant type of prey in the summer months as well as in October and November, while none of the other prey types contributed in a considerable degree.

Greater predation impact was exercised by the larger stages $\left(L_{4}\right.$ and $\left.L_{3}\right)$ of $A$. boyeri, while the numbers of larvae recovered from the stomach contents of the smaller $L_{1}$ and $L_{2}$ stages were remarkably lower. Indeed, in many sampling occasions, no E. trichonis larvae were found in the stomach contents of the younger $L_{1}$ specimens (Fig. 4). Estimates of the mean number of $E$. trichonis larvae preyed on by each individual of $A$. boyeri in the four size classes showed that the larger specimens were able to consume up to $16.35 \pm 4.4$ (mean $\pm \mathrm{SE}$ ) E. trichonis larvae (Fig. 4). It is interesting to 
report that a maximum number of 71 larvae were recovered from the stomach of a single $L_{4}$ individual in July.

Personal observations from the surface and underwater video recordings close to one lamp raft showed that a few minutes after switching on the light, a dense aggregation of zooplankton occurs and during the first hour the fish fry approach probably foraging for prey. As time progresses larger fish such as $A$. boyeri and other species approach, while after 3-4 h even the lake's largest fish species Scardinius acarnanicus Economidis, 1991, Carassius gibelio (Bloch, 1782), and Leucos ylikiensis (Economidis, 1991), approach and circle the lamp raft.

Estimations of the total number of E. trichonis larvae preyed upon each night by one $A$. boyeri fish school aggregated around a single lamp raft were made, based on the weight of the $A$. boyeri catch taken around each of the two lamp rafts in all fishing occasions (Fig. 5) and the weight-size distribution of the specimens measured in the laboratory. It must be emphasized that the fish catch around the APVR was always by 40-150 percentage points larger than the catch around the TR (Fig. 5). According to these estimates, the overall predation of one school of $A$. boyeri on E. trichonis larvae could reach a peak of $100321 \pm 18610$ individuals, as observed in June when only the APVR data were used in the calculations (Fig. 6). There was a considerable similarity between the two lamp rafts in the monthly variation of the overall predation (Fig. 6). Generally, higher values were estimated for the summer months for both lamp rafts, while the lowest predation was recorded in September with $336 \pm 0.0$ and $658 \pm 125)$ specimens around the APVR and TR, respectively.

\section{DISCUSSION}

One of the aims of this study was to investigate the feeding of Atherina boyeri in the proximity of purse seine artificial lights in Lake Trichonis and to compare its diet with two previous studies (Chrisafi et al. 2007, Doulka et al. 2013) in which the samples have been taken without the use of light. It must be pointed out, though, that direct comparisons are difficult to be made since both of the two previous studies have been conducted in monthly intervals for a full year, while the presently reported study for only seven months coinciding with the period of the main fishing activity with the use of light in Lake Trichonis. Table 2 summarizes the comparison between these studies.

In respect to the dietary composition, the presently performed stomach content analysis revealed the absence of helminth parasites (Cestoda and Nematoda), chironomid larvae, harpacticoid copepods, diatoms, and plant parts being reported by Chrisafi et al. (2007). Also the cladocerans Alona sp. and Leptodora kindtii were not found, in contrast to Doulka et al. (2013). On the other hand, no copepod nauplii were found in the diet of A. boyeri in the two previous studies. The larvae of the bivalve Dreissena blanci were the most important prey of $A$. boyeri in Lake Trichonis, as it was also reported by Chrisafi et al. (2007), although Doulka et al. (2013) found this taxon second in abundance. It should be noted, that according to recent investigations (Chalkia et al. 2012), Dreissena blanci had been misidentified as Dreissena polymorpha in both of these previous reports. The calanoid copepod Eudiaptomus drieschi, which dominates the zooplankton community in Lake Trichonis (Doulka and Kehayias 2008), was the most important prey of

Table 1

The number of prey items $(n)$ and the frequency of occurrence $(F)$ of the prey categories found in the stomach contents of Atherina boyeri specimens caught around the two lamp rafts in Lake Trichonis, Greece (The respective values in June came from samples taken only around TR)

\begin{tabular}{|c|c|c|c|c|c|c|c|c|c|c|c|c|c|c|}
\hline \multirow{2}{*}{ Prey category } & \multicolumn{2}{|c|}{ June } & \multicolumn{2}{|c|}{ July } & \multicolumn{2}{|c|}{ August } & \multicolumn{2}{|c|}{ September } & \multicolumn{2}{|c|}{ October } & \multicolumn{2}{|c|}{ November } & \multicolumn{2}{|c|}{ December } \\
\hline & $n$ & $F$ & $n$ & $F$ & $n$ & $F$ & $n$ & $F$ & $n$ & $F$ & $n$ & $F$ & $n$ & $F$ \\
\hline Eudiaptomus drieschi (adults) & 299 & 19.05 & 20 & 5.9 & 55 & 1.9 & 0 & 0.0 & 0 & 0.0 & 0 & 0.0 & 21 & 2.9 \\
\hline E. drieschi (copepodids) & 9 & 9.52 & 3 & 1.6 & 0 & 0.0 & 0 & 0.0 & 0 & 0.0 & 0 & 0.0 & 0 & 0.0 \\
\hline E. drieschi (total) & 308 & 25.00 & 23 & 5 & 55 & 1.9 & 0 & .0 & 0 & 0.0 & 0 & 0.0 & 21 & 2.9 \\
\hline Cyclopoida (adults) & 11 & 5.95 & 9 & 3.2 & 2 & 0.6 & 0 & 0.0 & 0 & 0.0 & 0 & 0.0 & 0 & 0.0 \\
\hline Cyclopoida (c & 12 & 8.33 & 18 & 7 & 0 & 0.0 & 0 & 0.0 & 0 & 0.0 & 0 & 0.0 & 2 & 1.4 \\
\hline Cyclopoida (total) & 23 & 10.71 & 27 & 9.7 & 2 & 0.6 & 0 & 0.0 & 0 & 0.0 & 0 & 0.0 & 2 & 1.4 \\
\hline Copepod nauplii & 24 & 10.71 & 201 & 25.3 & 6 & 2.6 & 0 & 0.0 & 4 & 1.3 & 14 & 4.6 & 28 & 12.3 \\
\hline Dreissena blanci larvae & 8043 & 79.76 & 30810 & 78.5 & 3697 & 71.6 & 16156 & 97.4 & 13047 & 91.0 & 1104 & 88.0 & 1975 & 87.7 \\
\hline Daphnia cucullata & 0 & 0.00 & 4 & 1.6 & 0 & 0.0 & 0 & 0.0 & 0 & 0.0 & 0 & 0.0 & 0 & 0.0 \\
\hline Diaphanosoma orghidani & 24 & 14.29 & 14 & 5.9 & 0 & 0.0 & 0 & 0.0 & 3 & 1.3 & 0 & 0.0 & 0 & 0.0 \\
\hline Bosmina longirostris & 265 & 39.29 & 452 & 37.1 & 33 & 11.0 & 1 & 0.9 & 117 & 16.1 & 17 & 6.9 & 20 & 10.9 \\
\hline Ceriodaphnia pulchella & 1 & 1.19 & 0 & 0.0 & 0 & 0.0 & 0 & 0.0 & 0 & 0.0 & 0 & 0.0 & 0 & 0.0 \\
\hline Amphipods & 31 & 8.33 & 259 & 28.5 & 18 & 5.8 & 1 & 0.9 & 18 & 7.1 & 15 & 6.9 & 0 & 0.0 \\
\hline $\begin{array}{l}\text { Economidichthys trichonis } \\
\text { larvae }\end{array}$ & 545 & 55.95 & 681 & 43.0 & 617 & 50.3 & 12 & 9.4 & 221 & 34.8 & 449 & 34.3 & 50 & 11.6 \\
\hline Atherina boyeri larvae & 0 & 0.00 & 4 & 2.2 & 0 & 0.00 & 0 & 0.00 & 1 & 0.6 & 1 & 0.6 & 4 & 1.4 \\
\hline Insects & 3 & 3.57 & 8 & 3.8 & 4 & 2.6 & 0 & 0.0 & 1 & 0.6 & 0 & 0.0 & 0 & 0.0 \\
\hline Total number of prey items & 9598 & & 32483 & & 4432 & & 16170 & & 13412 & & 1600 & & 2100 & \\
\hline
\end{tabular}




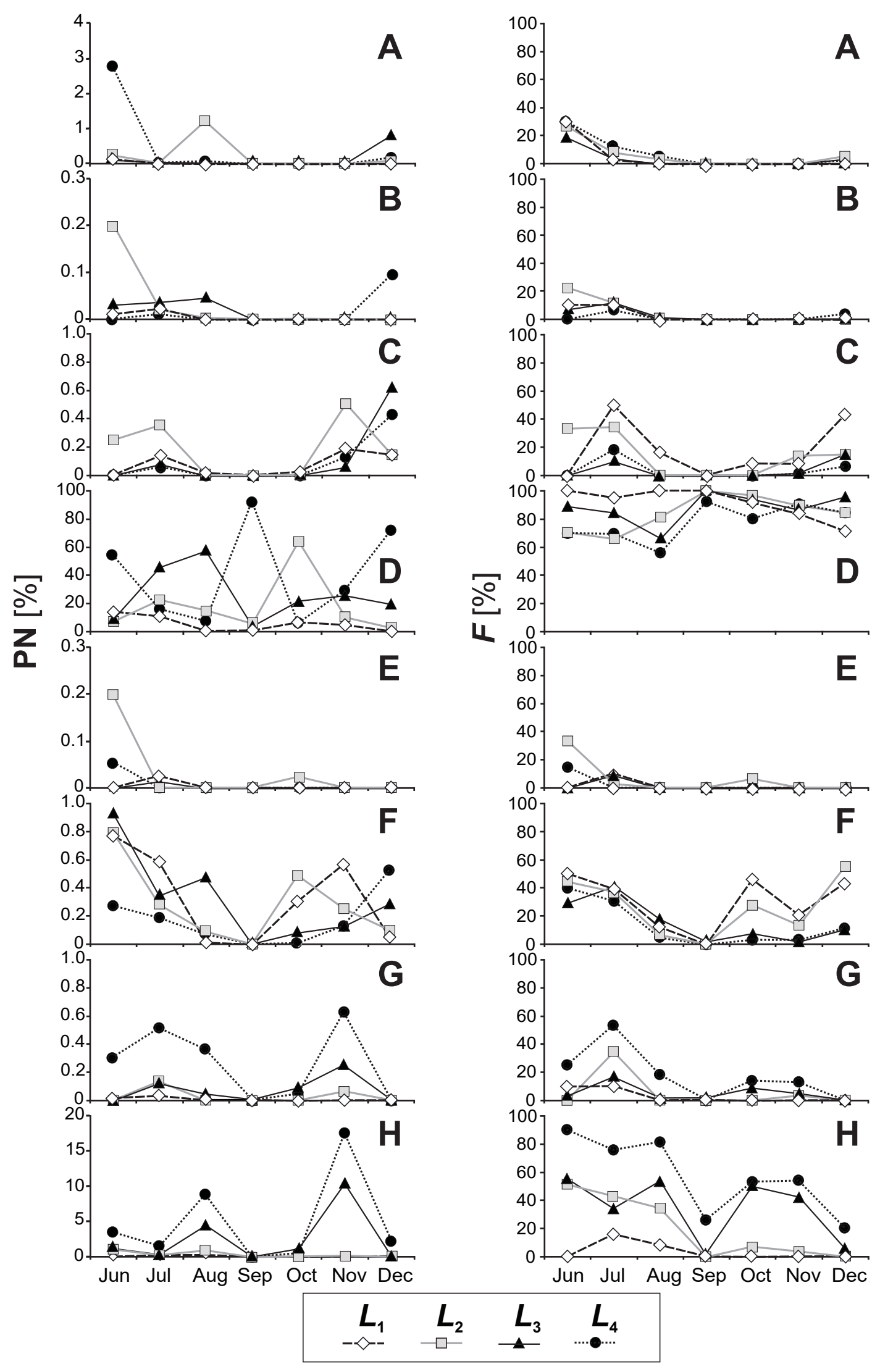

Fig. 2. Relative prey abundance (PN) and frequency of occurrence $(F)$ of prey types found in the stomach contents of the four length classes of Atherina boyeri specimens caught using both lamp rafts in Lake Trichonis, Greece: Eudiaptomus drieschi (adults and copepodids) (A), Cyclopoid copepods (adults and copepodids) (B), Copepod nauplii $(\mathbf{C})$, Dreissena blanci larvae $(\mathbf{D})$, Diaphanosoma orghidani $(\mathbf{E})$, Bosmina longirostris $(\mathbf{F})$, Amphipods $(\mathbf{G})$, Economidichthys trichonis larvae (H) 
A. boyeri according to Doulka et al. (2013) and second in prey abundance according to Chrisafi et al. (2007). On the contrary, in the presently reported study, E. drieschi had significantly lower importance as prey.

The absence of rotifers from the $\operatorname{diet}$ of $A$. boyeri was not unexpected, since this was also reported in the previous studies conducted in this area (Chrisafi et al. 2007, Doulka et al. 2013), as well as in other freshwater and brackish ecosystems (Mantilacci et al. 1990, Rosecchi and Crivelli 1992, Bartulović et al. 2004). Also, according to all the above studies, A. boyeri appears not to prey on other small-bodied organisms such as copepod nauplii, whose presence in the stomach contents has been characterized as rare or even accidental. In contrast, in the presently reported study nauplii were a significant prey for $A$. boyeri, and they prevailed in the diet especially of its younger ontogenetic stages. One explanation for this could be that the nauplii, being attracted to the light source and aggregating there in greater densities than normal, thus became an enticing prey especially for the smaller members of the $A$. boyeri population. The latter, being also attracted to the light, tend to prey on smaller organisms since they are not physically able to consume larger ones (due to mouth gape size), or face intense intra-specific competition with the larger ontogenetic stages.

In contrast to the previous reports, the larvae of Economidichthys trichonis and the amphipods were among the most important prey items in this study, presenting moderate $\mathrm{PN}$ values, but highly elevated $F$ values. The presence of finfish fry has been reported in both previous studies, however, the specimens either were not identified to species (Chrisafi et al. 2007), or identified as belonging to $E$. trichonis and $A$. boyeri, although not counted separately (Doulka et al. 2013). Thus, direct comparisons of the contribution of E. trichonis larvae in the diet of $A$. boyeri cannot be made. Previous investigations using light traps in Lake Trichonis have confirmed the phototactic behaviour of various fish larvae

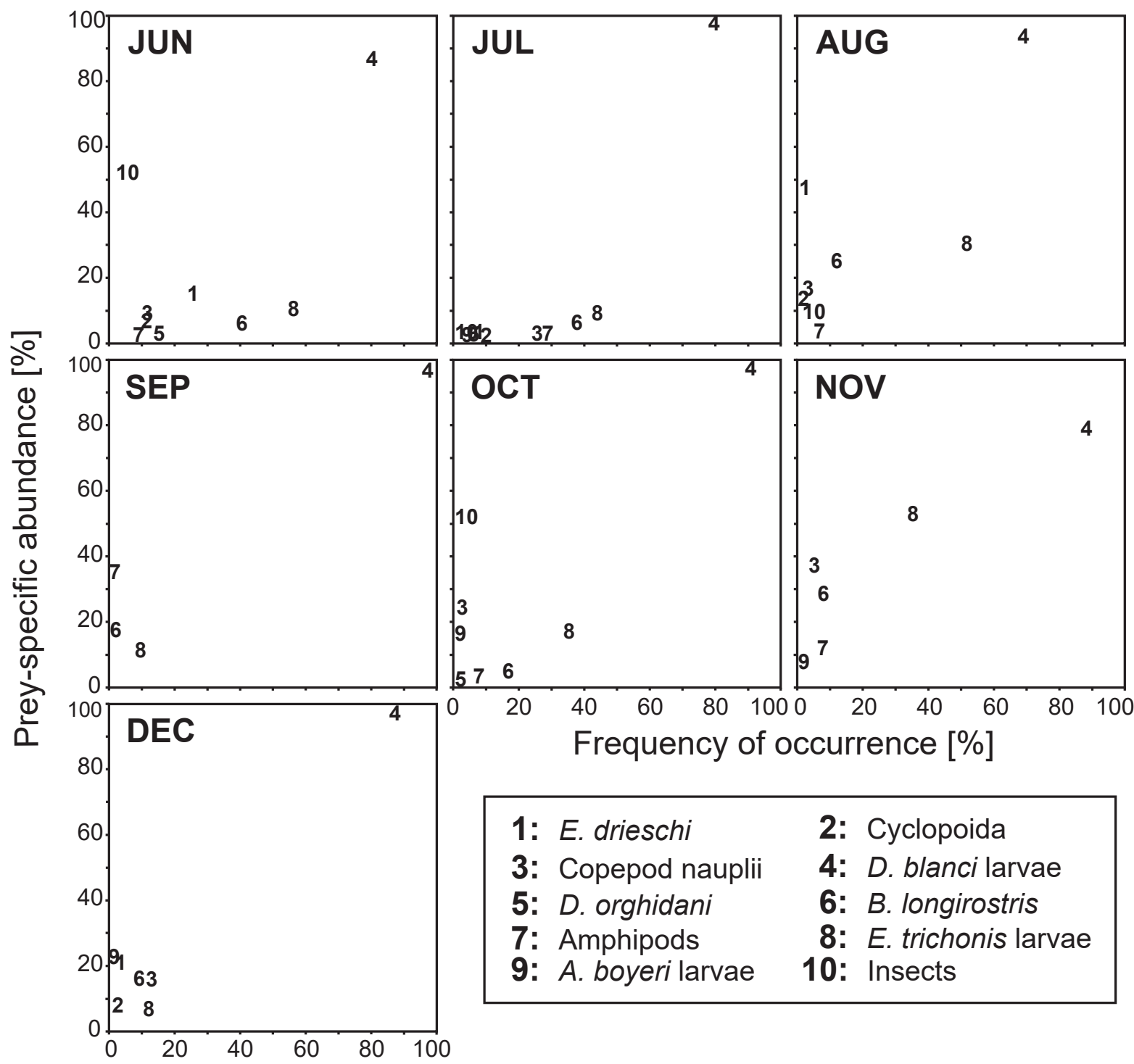

Fig. 3. Graphical analysis of the feeding strategy of Atherina boyeri in each month between June and December 2014 in Lake Trichonis, Greece, using the modified Costello method 
(among which E. trichonis) and amphipods (Kehayias and Doulka 2007, Kehayias, unpublished data). Thus, the light seems to act as a cue to attract the larger food items recovered from the stomach analysis, such as amphipods, larvae of E. trichonis and even terrestrial flying insects that possibly fell into the water and became prey for the larger specimens of $A$. boyeri that have the physical ability (mouth gape size) to grasp them.

Although the underwater video recordings did not enable the observation of specific predation incidents, it seems that the presence of a light source creates a food chain reaction and the size of the predators approaching the light increases with time (Maéda 1951, Ben-Yami 1976). As a lamp raft operates for 6-8 $\mathrm{h}$ before fishing, it is not possible to determine the predation processes occurring around the light during this entire time period. Therefore, stomach analysis of $A$. boyeri specimens caught at the end

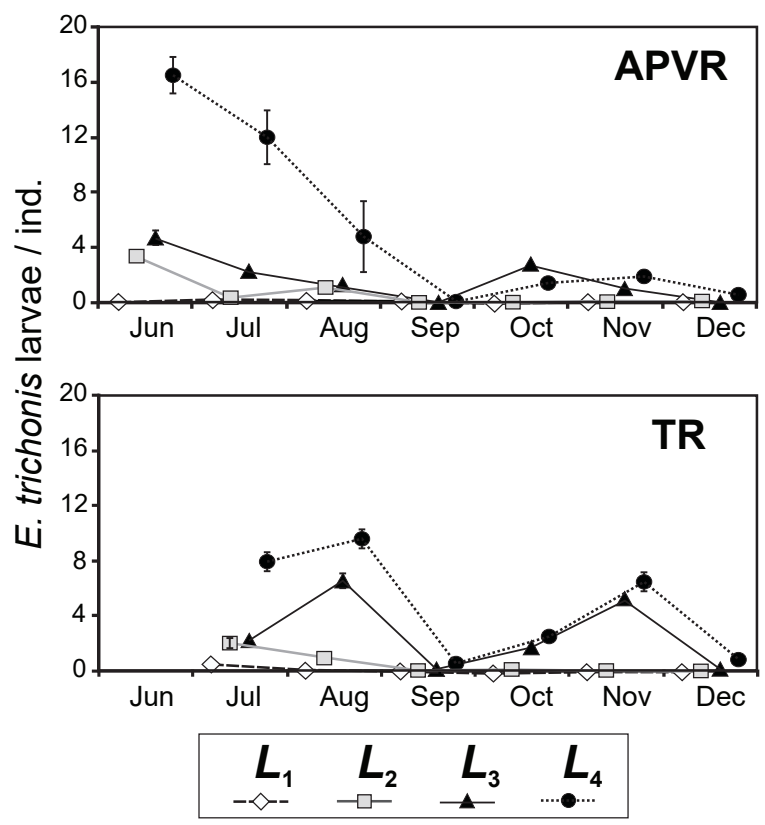

Fig. 4. The mean number of Economidichthys trichonis larvae consumed per individual of Atherina boyeri in each of the four size classes $\left(L_{1}\right.$ to $\left.L_{4}\right)$ and each raft type (APVR and TR) from June to December 2014 in Lake Trichonis, Greece; standard error is shown as vertical bar of this period poses serious limitations on the investigation of the actual time, duration and general conditions under which their prey has been consumed.

Results on the catch size of $A$. boyeri obtained around the two lamp rafts showed that the APVR was able to attract a greater number of fish specimens, which resulted in an overall increase of more than 60 percentage points of the catch size of the TR. Kehayias et al. (2016) discussed in detail the possible influence of light intensity and wavelength on these results and suggested that green

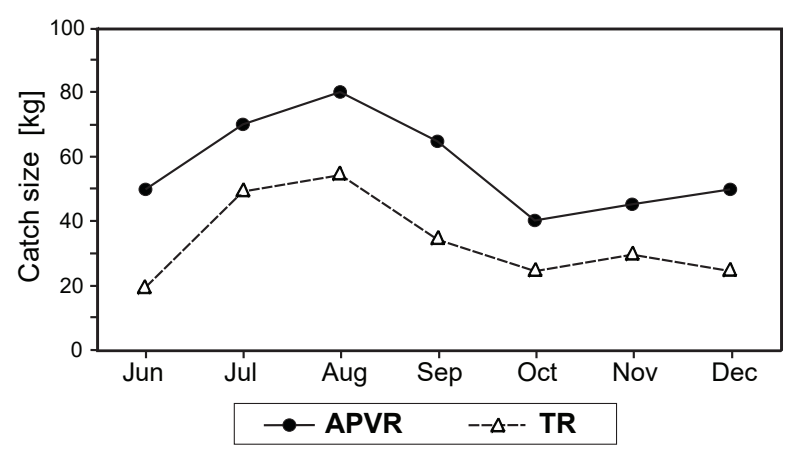

Fig. 5. Variation of the Atherina boyeri catch taken around the APVR and the TR from June to December 2014 in Lake Trichonis, Greece

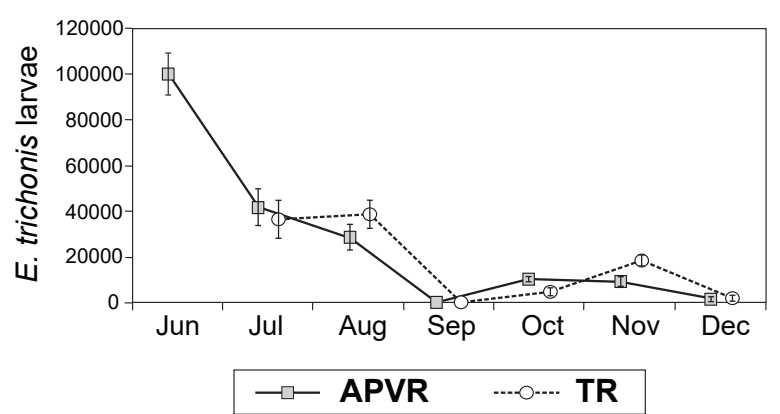

Fig. 6. The number of Economidichthys trichonis larvae estimated to have been consumed by a single Atherina boyeri school around each raft (APVR and TR) during each sampling session in Lake Trichonis, Greece; standard error is shown as vertical bar

Table 2

Selected feeding and sampling characteristics of Atherina boyeri in Lake Trichonis, Greece

\begin{tabular}{lccc}
\hline \multirow{2}{*}{ Parameter } & \multicolumn{3}{c}{ Reference } \\
\cline { 2 - 4 } & This study & Doulka et al. 2013 & Chrisafi et al. 2007 \\
\hline Sampling duration [months] & 7 & 12 & 12 \\
Total number of A. boyeri examined & 1300 & 590 & 240 \\
Number of taxa found in the diet & 12 & 13 & 15 \\
Dominant taxon in the diet & Dreissena blanci & Eudiaptomus drieschi & Dreissena blanci (as D. polymorpha) \\
Presence of rotifers in the diet & No & No & No \\
Presence of copepod nauplii in the diet & Yes & No & No \\
Contribution of E. trichonis in the diet & Second in prevalence & Identified but not counted & Fish fry (not identified to species) \\
Contribution of amphipods in the diet & Fourth in prevalence & Negligible & Negligible \\
\hline
\end{tabular}


light may attract more of the lake's zooplankton than white light. However, the stomach analysis undertaken in this study showed no significant differences in feeding intensities or dietary preferences of $A$. boyeri between the two light colours used. Moreover, the lack of differences in the sizes of the A. boyeri specimens caught around the two lamp rafts means that both green and white lights may equally attract the members of this fishes' population and does not prove a higher attraction to green. Thus, the differences observed between the catch sizes cannot be sufficiently explained by the methodology used in this study. Therefore, a more thorough field investigation using different sampling design must be conducted in order to determine the approach and predation processes of fish and zooplankton near a light source.

Economidichthys trichonis is the smallest freshwater European teleost and it is endemic to lakes Trichonis and Lysimachia. The species has been rated as "Endangered" in the IUCN Red List which refers the main threats to its population as being: eutrophication (of Lake Lysimachia), loss of reed beds due to land reclamation, lake level decline due to water extraction for irrigation, and potential habitat impacts due to bottom trawling (Crivelli 2006). The presently reported study provides the first report of a new possible threat to this endemic species due to the particular fishing technique carried out in Lake Trichonis. The results showed that E. trichonis larvae, being attracted to the light of lamp rafts, might be heavily predated on by A. boyeri, especially by the larger specimens, many of which tend to be voracious and ingest numerous items. Usually, the larvae found in the stomach contents of these large A. boyeri specimens were of the same size and in a similar stage of digestion. This probably indicates that their predators attacked and ingested them within a short time span when a swarm of these coeval larvae approached the fishing light.

The estimates of the predation impact of one school of A. boyeri around a single lamp raft showed values of several thousand larvae per night. Taking into consideration that the Greek legislation for this area allows three fishing boats, each with three lamp rafts, to practise the purse seine method simultaneously, the overall predation is estimated to reach several hundreds of thousands of larvae per night being removed from the lake's ecosystem in certain seasons. In fact, the real predation impact cannot be estimated precisely due to extensive illegal fishing with light that is practised within the lake. Although there are no estimates of the current population size of E. trichonis in Lake Trichonis, the predation of its larvae by another fish species due to the use of fishing lights may pose a conservation issue. However, from August onward, the contribution of E. trichonis larvae in the $\operatorname{diet}$ of $A$. boyeri decreased considerably, probably due to the maturation of the former in autumn and the alteration of their distribution pattern from the planktonic to the benthic state (Daoulas et al. 1993). Considering also that the purse seine fishing of A. boyeri is prohibited for nearly a summer month (15 of June to 20 of July) in order to protect its breeding, the impact of fisheries to E. trichonis larvae could be insignificant. Consequently, based on the presently reported results, an extension of the purse seine prohibition for two full months (June-July) seems a reasonable suggestion, taking into account the socio-economic consequences of a gear prohibition to the local economy of this fisheriesdependent area. In any case, there is a need to investigate further the ecological processes that take place around a light source in this aquatic ecosystem in order to provide solid scientific evidence for the authorities to modify the current fishery legislation for Lake Trichonis.

The presently reported study revealed that fishing with light might alter the dietary preference of the target fish species and even of the entire fish community. This may have serious consequences on the younger ontogenetic stages of other fish populations, especially when it coincides with their reproductive period. In conclusion, although fishing with light is practised in various forms in marine and freshwater ecosystems all over the world, the consequences of this practice remain unknown. Therefore the present preliminary study anticipates stimulating analogous field investigations worldwide.

\section{ACKNOWLEDGEMENTS}

The authors wish to thank the fisherman Giorgos Zarkadas and his crew for their assistance in the field operations.

\section{REFERENCES}

Acros J.M., Oro D. 2002. Significance of nocturnal purse seine fisheries for seabirds: A case study off the Ebro Delta (NW Mediterranean). Marine Biology 141 (2): 277-286. DOI: 10.1007/s00227-002-0828-3

Amundsen P.A., Gabler H.M., Staldvik F.J. 1996. A new approach to graphical analysis of feeding strategy from stomach contents data-modification of the Costello (1990) method. Journal of Fish Biology 48 (4): 607-614. DOI: 10.1111/j.1095-8649.1996. tb01455.x

Bartulović V., Lučić D., Conides A., Glamuzina B., Dulčić J., Hafner D., Batistić M. 2004. Food of sand smelt, Atherina boyeri Risso, 1810 (Pisces: Atherinidae) in the estuary of the Mala Neretva River (middle-eastern Adriatic, Croatia). Scientia Marina 68 (4): 597-603. DOI: 10.3989/scimar.2004.68n4597

Ben-Yami M. 1976. Fishing with light. FAO fishing manuals. Fish News Books Ltd, Farnham, Surrey, UK.

Chalkia E., Kehayias G., Doulka E. 2012. Spatial and temporal variation of the freshwater mussel Dreissena blanci (Westerlund, 1890) larvae in Greek lakes. Malacologia 55 (1): 135-150. DOI: 10.4002/040.055.0109

Chrisafi E., Kaspiris P., Katselis G. 2007. Feeding habits of sand smelt (Atherina boyeri, Risso 1810) in Trichonis Lake (western Greece). Journal of Applied Ichthyology 23 (3): 209-214. DOI: 10.1111/j.14390426.2006.00824.x

Crivelli A.J. 2006. Economidichthys trichonis. The IUCN RedList of Threatened Species 2006: e.T7021A12822955. (Accessed on 12 March 2016.) DOI: 10.2305/IUCN. UK.2006.RLTS.T7021A12822955.en 
Daoulas C., Economou A.N., Psarras T., BarbieriTseliki R. 1993. Reproductive strategies and early development of three freshwater gobies. Journal of Fish Biology 42 (5): 749-776. DOI: 10.1111/j.10958649.1993.tb00382.x

Doulka E., Kehayias G. 2008. Spatial and temporal distribution of zooplankton in Lake Trichonis (Greece). Journal of Natural History 42 (5-8): 575595. DOI: $10.1080 / 00222930701835555$

Doulka E., Kehayias G., Chalkia E., Leonardos I. 2013. Feeding strategies of Atherina boyeri (Risso 1810) in a freshwater ecosystem. Journal of Applied Ichthyology 29 (1): 200-207. DOI: 10.1111/jai.12012

El-Haweet A. 2001. Catch composition and management of daytime purse seine fishery on the southern Mediterranean Sea coast, Abu Qir Bay, Egypt. Mediterranean Marine Science 2 (2): 119-126. DOI: $10.12681 / \mathrm{mms} .270$

Hyslop E.J. 1980. Stomach content analysis - a review of methods and their application. Journal of Fish Biology 17 (4): 411-429. DOI: 10.1111/j.1095-8649.1980. tb02775.x

Kehayias G., Doulka E. 2007. A light trap for sampling Atherina boyeri larvae in Lake Trichonis, Greece. Journal of Freshwater Ecology 22 (3): 533-534. DOI: $10.1080 / 02705060.2007 .9664184$

Kehayias G., Doulka E. 2014. Trophic state evaluation of a large Mediterranean lake utilizing abiotic and biotic elements. Journal of Environmental Protection 5 (1): 17-28. DOI: $10.4236 /$ jep.2014.51003

Kehayias G., Tzavali A., Gini M., Michopoulou E. 2015. Predation of Atherina boyeri upon the endangered fish Economidichthys trichonis: The role of the purse seine fishery lights. P. 352. In: Abstract Book, ICCB: 27th International Congress for Conservation Biology, 4th European Congress of Conservation Biology, 2-6 August 2015, Montpellier, France.

Kehayias G., Bouliopoulos D., Chiotis N., Koutra P. 2016. A photovoltaic-battery-LED lamp raft design for purse seine fishery: Application in a large Mediterranean lake. Fisheries Research 177: 18-23. DOI: 10.1016/j.fishres.2016.01.003

Leonardos I.D. 2001. Ecology and exploitation pattern of a landlocked population of sand smelt, Atherina boyeri (Risso 1810), in Trichonis Lake (western Greece). Journal of Applied Ichthyology 17 (6): 262-266. DOI: 10.1046/j.1439-0426.2001.00296.x

Maéda H. 1951. Analytical studies on marine lampcommunities. Publications of the Seto MarineBiological Laboratory 1 (4): 195-213. DOI: 10.5134/174444

Mantilacci L., Mearelli M., Giovinazzo G., Lorenzoni M. 1990. Accrescimento e alimentazione del latterino
(Atherina boyeri Risso) del lago Trasimeno. [Increase and feeding of sand smelt (Atherina boyeri Risso) of Lake Trasimeno.] Rivista di Idrobiologia 29 (1): 309 327. [In Italian.]

Marchesan M., Spoto M., Verginella L., Ferrero E.A. 2005. Behavioural effects of artificial light on fish species of commercial interest. Fisheries Research $\mathbf{7 3}$ (1-2): 171-185. DOI: 10.1016/j.fishres.2004.12.009

Matsushita Y., Azuno T., Yamashita Y. 2012. Fuel reduction in coastal squid jigging boats equipped with various combinations of conventional metal halide lamps and low-energy LED panels. Fisheries Research 125-126: 14-19. DOI: 10.1016/j.fishres.2012.02.004

McHenry M.P., Doepel D., Onyango B.O., Opara U.L. 2014. Small-scale portable photovoltaic-batteryLED systems with submersible LED units to replace kerosene-based artisanal fishing lamps for subSaharan African lakes. Renewable Energy 62: 276-84. DOI: 10.1016/j.renene.2013.07.002

Mills E., Gengnagel T., Wollburg P. 2014. SolarLED alternatives to fuel-based lighting for night fishing. Energy for Sustainable Development 21: 30 41. DOI: $10.1016 /$ j.esd.2014.04.006

Okamoto T., Takahashi K., Ohsawa H., Fukuchi K., Hosogane K., Kobayashi S., Moniwa M., Sasa K., Yoshino H., Ishikawa H., Harada M., Asakura K., Ishii H. 2008. Application of LEDs to fishing lights for Pacific saury. Journal of Light and Visual Environment 32 (2): 88-92. DOI: 10.2150/jlve.32.88

Papaconstantinou C., Farrugio H. 2000. Fisheries in the Mediterranean. Mediterranean Marine Science 1 (1): 5-18. DOI: $10.12681 / \mathrm{mms} .2$

Rosecchi E., Crivelli A.J. 1992. Study of a sand smelt (Atherina boyeri Risso 1810) population reproducing in freshwater. Ecology of Freshwater Fish 1 (2): 7785. DOI: 10.1111/j.1600-0633.1992.tb00076.x

Sokimi W., Beverly S. 2010. Small-scale fishing techniques using light: A manual for fishermen. Secretariat of the Pacific Community, Noumea, New Caledonia, France.

Tsagarakis K., Vassilopoulou V., Kallianiotis A., Machias A. 2012. Discards of the purse seine fishery targeting small pelagic fish in the eastern Mediterranean Sea. Scientia Marina 76 (3): 561-572. DOI: 10.3989/ scimar.03452.02B

Tsitsika E.V., Maravelias C.D. 2008. Fishing strategy choices of purse seines in the Mediterranean: Implications for management. Fisheries Science $\mathbf{7 4}$ (1): 19-27. DOI: 10.1111/j.1444-2906.2007.01492.x

Zar J.H. 1999. Biostatistical Analysis. 4th edn. Prentice Hall, Upper Saddle River, NJ, USA.

Received: 22 October 2017

Accepted: 26 January 2018

Published electronically: 31 March 2018 